\title{
THE POSSIBILITY OF USING FLORAL ANALYSIS TO DIAGNOSE THE NUTRITIONAL STATUS OF PEAR TREES
}

Manuel Sanz

Luís Montañés

E. E. de Aula Dei (CSIC)

Apartado 202. 50080 Zaragoza (España).
Manuel Carrera

Servicio de Investigación Agraria

Apartado 727. 50080 Zaragoza

España

\section{$\underline{\text { Abstract }}$}

Floral analysis, due to the time at which it is performed, gives appreciably earlier results than leaf analysis. This paper will explore the possibility of using it to predict $\mathrm{Fe}$ and $\mathrm{Mn}$ content of leaves taken 120 days after full bloom. Given the increase in the degree of variation of Fe content in flowers compared to that of leaves, this could be a good way of predicting iron chlorosis.

\section{Introduction}

The diagnosis of nutrients present in crops via the interpretation of floral and foliar analysis constitutes, at present, the best and most commonly used way of evaluating the nutritional status of plants. This proves to be of great importance for crop yield.

This practice, which has been widely tested, establishes that by evaluating the nutrients present in leaves we can establish the nutritional status of the plant. The proven relationship between the quantity of a plant's nutrients and yield enables us to use leaf analysis to improve nutrition and yield, by means of appropriate growing techniques. An important improvement in this area was the application of DRIS methodology (Beaufils, 1973;Davee et al., 1986; Goh and Malakouti, 1992; Parent and Granger, 1989; Sumner, 1986; Szucs et al, 1990) and later on the DOP methodology (Montañés et al, 1993).

The practical application of this technique has several limitations. One of the conditioning factors is the time when its application is possible. Bergmann (1992) points out that a possible improvement in yield and in the quality and quantity of crops by supplementing the fertilization during the growth cycle, where necessary, will only be effective if applied in time.

At present, the standard time for leaf sampling on fruit trees is 120 days after full bloom, midsummer in the Northern Hemisphere. Past research (Sanz et al, 1992 a) has managed to bring this time forward to 60 days after full bloom in peach trees or even to extend it to include the whole vegetative cycle (Sanz et al, 1993 a). Other writers have found it possible to bring diagnosis forward for trees such as peach (Leece et al, 1974), apricot ( Leece et al,1975a), plum (Leece,1975b), and cherry (Leece,1975c), by establishing mathematical formulae, which are then applied in order to 
transform reference values into foliar diagnosis. As a solution to this same problem, other studies recommend the use of the DRIS system, which enables leaf analysis to be applied throughout the vegetative cycle. Nevertheless, this system has yet to be fully approved.

Floral analysis offers the possibility of determining the nutritional status of crops and correcting deficiencies, if necessary, at an earlier stage. In a study on peach trees (Sanz et al, 1992 a), carried out parallel to this one, a close correlation was found to exist between the nutrient content $(\mathrm{N}, \mathrm{P}, \mathrm{K}, \mathrm{Ca}, \mathrm{Mg}$, $\mathrm{Fe}, \mathrm{Mn}, \mathrm{Cu}$ and $\mathrm{Zn}$ ) of leaves taken 120 days after full bloom and the content of these same nutrients found in flowers. The application of floral analysis on pear trees and the subsequent diagnosis would mean that nutritional problems could be spotted at an earlier stage. It has already been established that there is a direct relationship between the mineral content of leaves and yield (Sanz et al, 1993 a). We will therefore try to find a relationship between the nutrient content of leaves and that of flowers, and indirectly relate the latter to harvest yield.

\section{Materials and methods}

The study was carried out on 100 pear tree (Pyrus communis. L.) orchards, located in the main production areas of this fruit tree in the Mid Ebro Basin, $\mathrm{N}$ E Spain. The only criteria used when choosing the orchards was that they should be in full bearing. Growing techniques, variety, soil type, etc. were not taken into account.

Nevertheless all the areas used for growing fruit trees in the studied region (Montañés et al,1975) have as common characteristics; fertile soil with high $\mathrm{pH}$ and high carbonate content and high active lime.

When the orchards were in full bloom, five trees were chosen from each and marked to ensure that successive samples would be taken from the same tree. Open flowers, including the stem, were taken from the central part of bearing branches, at full bloom, irrespective of the age of branches.

Sixty days after full bloom, ie, the second fortnight in May, leaf samples from the central third of new shoots were taken from the trees which had previously given the flower samples. This operation was then repeated during the second fortnight in July, 120 days after full bloom. Leaf samples were taken from the same trees and in the same way.

Both flowers and leaves were analyzed using methods proposed by the Inter-Institutes Committee (1969) and Pinta (1973) and results were expressed as percentage of dry matter for macroelements (N, P, K, Ca and $\mathrm{Mg}$ ) and as ppm of dry matter for microelements ( $\mathrm{Fe}, \mathrm{Mn}, \mathrm{Cu}$ and $\mathrm{Zn}$ ).

Statistical calculations were carried out using the SPSS computer program. 


\section{Results and discussion}

Table 1 shows some of the features obtained from the analysis of nutrients found in flowers from the pear trees which were used in this study.

Table 2 shows the same results obtained from the analysis of nutrients in pear tree leaves taken 120 days after full bloom.

If we compare the nutrients present in flowers with those present in leaves, (see tables 1 and 2) the following observations can be made:

$\mathrm{N}, \mathrm{P}$, and $\mathrm{K}$ are present in greater quantities in the flower.

$\mathrm{Ca}$ and $\mathrm{Mg}$ are present in greater quantities in the leaf.

If we consider the flower sample as a kind of initial leaf sample, the evolution of these nutrients is as to be expected (Sanz et al, 1993 a) from the knowledge we have about results only from leaf sampling. That is to say N, P and $\mathrm{K}$ levels continue to fall, whereas $\mathrm{Ca}$ and $\mathrm{Mg}$ rise, throughout the vegetative cycle.

The microelements $\mathrm{Fe}$ and $\mathrm{Cu}$ are found in greater quantities in flowers than in leaves, $\mathrm{Mn}$ in lesser and $\mathrm{Zn}$ in similar proportions.

The fact that a greater concentration of iron was found in flowers than in leaves and that the degree of variation of this element is also greater, could be of significance if it were possible to develop a method of early detection of iron chlorosis in pear trees (Sanz et al., 1992 b; Abadía et al., 1989)

Table 3 shows correlation and degree of significance between analytical results of flower samples and leaf samples taken 60 days after full bloom.

Table 4 shows correlation and degree of significance between analytical results of flower samples and leaf samples taken 120 days after full bloom (the standard time for leaf analysis in fruit trees).

It is clear from tables 3 and 4 that only Fe and Mn levels present in pear tree flowers and leaves show a significant correlation throughout the vegetative cycle up to 120 days after full bloom. These results contrast dramatically with those found for peach trees, in which all elements present in both flowers and leaves showed a close correlation. (Sanz et al, 1993 b)

As a result of these findings and by means of linear regression we can establish a number of equations which will allow us to predict the levels of Fe and Mn which we would expect to find in pear tree leaves taken 60 and 120 days after full bloom. (Table 5) 
The physiological behavior of the pear tree presents particular features and obvious differences have been found with that of the peach tree, when studied using the same method. Therefore, we are led to believe that to form the basis of a complete floral diagnosis of the pear tree it will be necessary to particularize between varieties and differentiate growing techniques. We can say then, as a conclusion that:

1.-Floral diagnosis of pear trees enables us to predict the Fe and Mn content of leaves up to 120 days after full bloom.

2.-The wider degree of variance of Fe content of pear tree flowers, led us to believe that the analysis of this element could help detect the presence of iron chlorosis at an earlier stage than through leaf analysis.

\section{Acknowledgments}

The authors wish to express their recognition to C. Fustero, C. Lope and J. Pascual for their technical contribution. This paper was supported by projects P. CA 6/91 (Research Advisory Board-Diputación General de Aragón) and AGR89-0502 (National Plan for Agricultural Research).

\section{$\underline{\text { References }}$}

Abadía, A; Sanz, M.; de las Rivas, J.; Abadía, J. (1989). Photosynthetic pigments and mineral composition of iron deficient pear leaves. J. Plant Nutr.12(7):827-838

Beaufils, E.R. 1973. Diagnosis and Recommendation Integrated System (DRIS). Soil Sci. Bul. 1. University of Natal (S. Africa), pp.132

Bergman, W. (Ed.) (1992) Nutritional Disorders of Plants. Gustav Fischer. Jena(Alemania). p. 337.

Comite Inter-Institutos (C.I.I.) (1969) Métodos de referencia para la determinación de elementos minerales en vegetales. An. Edaf. Agrobiol. XXVIII : 403-417.

Davee DE, Righetti TL, Fallahi E and Robbins S 1986 An evaluation of the DRIS approach for identifying mineral limitations on yield in "Napoleon" sweet cherry. J. Amer. Soc. Hort. Sci. 111, 988-993.

Goh KM and Malakouti MJ 1992 Preliminary Nitrogen, Phosphorus, Potassium, Calcium and Magnesium DRIS norms and indices for apple orchards in Canterbury, New Zealand. Commun. Soil Sci. Plant Anal. 23, 1371-1385.

Leece, D.R. and A. R. Gilmour (1974) Diagnostic leaf analysis for stone fruit. 2- Seasonal changes in the leaf composition of peach. Austral J. Exp. Agric. Anim. Husb. $14: 822-827$.

Leece, D.R. and B. van den Ende 1975a. Diagnostic leaf analysis for stone fruit. G. Apricot. Austral. J. Exp. Agric. Anim. Husb. 15: 123-128.

Leece, D.R. 1975 b. Diagnostic leaf analysis for stone fruit 4. Plum. Austral. J. Exp. Agric. Anim. Husb. 15: 112-17. 
Leece, D.R. 1975 c. Diagnostic leaf analysis for stone fruit 5. Sweet cherry. Austral. J. Exp. Agric. Anim. Husb. 15: 118-22.

Montañés, L.; M. sanz y L. Heras (1975) Fertilidad actual de los suelos dedicados a frutales en regadíos de la cuenca del Ebro. An. Aula Dei. 13 (12) : 167-178.

Montañés, L.; L. Heras, J. Abadía y M. Sanz (1993) Plant analysis interpretation based in a new index: Deviation from Optimum Percentage (DOP). J. Plant Nutr. 16 (9).

Parent LE and Granger, RL 1989 Derivation of DRIS norms from a highdensity apple orchard established in the Quebec Appalachian Mountains. J. Amer. Soc. Hort. Sci. 114, 915-919.

Pinta, M. et C.I.I. (1973) Méthodes de référence pour la détermination des éléments mineraux dans les végétaux. Détérmination des élements $\mathrm{Ca}$, $\mathrm{Mg}, \mathrm{Fe}, \mathrm{Mn}, \mathrm{Zn}$, et $\mathrm{Cu}$ par absorption atomique. Oléagineux, 28 : 87-93.

Sanz, M.; L. Heras and L. Montañés (1992 a) Relationships between yield and leaf nutrient contents in peach trees: Early nutritional status diagnosis. J. Plant. Nutr. 15 (9) : 1457-1466.

Sanz, M.; Cavero, J. and Abadía, J. (1992 b). Iron Chlorosis in the Ebro River Basin, Spain. J. Plant. Nutr. 15 (10) : 1971-1981.

Sanz, M.; L. Montañes (1993 a) Diagnóstico foliar continuado en melocotonero: Valores de Referencia. ITEA. $n^{\circ} 84$ (1).

Sanz, M.; J. Val y L. Montañés (1993 b) Is it possible a nutritional diagnosis in peach tree by the chemical analysis of the flowers?. Comunicacion al 2nd Inter. Symp. Diag. Nutr. Status Decid. Fruit Orchards. San Michelle all'Adige (Italia).

Sumner ME 1986 Diagnosis and Recommendation Integrated System (DRIS) as a guide to orchards fertilization. Food \& Fertil. Technology Center, Ext Bull 231 FFTC/ASPAC. Taipei, Taiwan, ROC.

Szücs E, Kalley T and Szenci Gy 1990 Determination of DRIS indices for apple (Malus domestica Borkh). Acta Horticulturae 274, 443-453.

Table 1. Analytical results obtained from pear tree flowers.

\section{Elements}

$\mathrm{N} \%$

P\%

$\mathrm{K} \%$

$\mathrm{Ca} \%$

$\mathrm{Mg} \%$

Fe ppm

Mn ppm

Cu ppm

Zn ppm
Content

\begin{tabular}{|c|c|}
\hline Maximum & Minimum \\
\hline 3.948 & 2.856 \\
\hline 0.712 & 0.396 \\
\hline 3.010 & 1.390 \\
\hline 1.380 & 0.190 \\
\hline 0.406 & 0.227 \\
\hline 471.30 & 69.90 \\
\hline 52.20 & 14.40 \\
\hline 602.90 & 14.40 \\
\hline 188.00 & 18.30 \\
\hline
\end{tabular}


Table 2. Analytical results obtained from pear tree leaves taken 120 days after full bloom.

Elements

Content

\begin{tabular}{lccc} 
& Average & Maximum & Minimum \\
$\mathrm{N}$ & 2.337 & 2.912 & 1.316 \\
$\mathrm{P} \%$ & 0.171 & 0.306 & 0.106 \\
$\mathrm{~K} \%$ & 0.839 & 1.920 & 0.210 \\
$\mathrm{Ca} \%$ & 1.359 & 2.080 & 0.790 \\
$\mathrm{Mg} \%$ & 0.356 & 0.529 & 0.203 \\
$\mathrm{Fe} \mathrm{ppm}$ & 126.88 & 300.00 & 42.80 \\
$\mathrm{Mn} \mathrm{ppm}$ & 47.94 & 125.40 & 13.60 \\
$\mathrm{Cu} \mathrm{ppm}$ & 24.44 & 72.10 & 9.00 \\
Zn ppm & 58.72 & 194.70 & 10.30 \\
\hline
\end{tabular}

Table 3. Correlation and significance $(* * 99 \%)$ of nutrient contents of pear tree flowers and leaves taken 60 days after full bloom.

N\% $\mathrm{P} \% \quad \mathrm{~K} \% \quad \mathrm{Ca} \% \quad$ Mg\% $\quad$ Fe ppm. Mn ppm. Cu ppm Znppm. $\begin{array}{lllllllll}0,161 & 0,163 & 0,100 & 0,155 & 0,056 & 0,434^{* *} & 0,427^{* *} & 0,019 & -0,096\end{array}$

Table 4 . Correlation and significance $\left({ }^{*} 99 \%\right)$ of nutrient contents of pear tree flowers and leaves taken 120 days after full bloom.

$\underline{\mathrm{N} \%} \quad \mathrm{P} \% \quad \mathrm{~K} \% \quad \mathrm{Ca} \% \quad \mathrm{Mg} \%$ Fe ppm. Mn ppm. Cu ppm $\underline{\mathrm{Zn} p \mathrm{pm} .}$ $\begin{array}{lllllllllll}0,056 & -0,136 & 0,082 & 0,088 & -0,004 & 0,349^{* *} & 0,341^{* *} & -0,079 & 0,118\end{array}$

Table 5. Linear regression equations to predict nutrient content of leaves taken 60 and 120 days after full bloom, based on flower analysis.

Degree of freedom Standard Error Equation

\begin{tabular}{lllll}
92 & 31.77 & $\mathrm{Fe}(60 \mathrm{~d})=0.193 \mathrm{Fe}(\mathrm{fl})+21.13$ & & 0.0001 \\
93 & 45.74 & $\mathrm{Fe}(120 \mathrm{~d})=0.215 \mathrm{Fe}(\mathrm{fl})+85.18$ & 0.0006 \\
92 & 13.47 & $\mathrm{Mn}(60 \mathrm{~d})=1.021 \mathrm{Mn}(\mathrm{fl})+11.2$ & 0.0001 \\
93 & 21.26 & $\mathrm{Mn}(120 \mathrm{~d})=1.243 \mathrm{Mn}(\mathrm{fl})+13.58$ & 0.0008 \\
\hline
\end{tabular}

$\mathrm{Fe}(60 \mathrm{~d})=\mathrm{Fe}$ content of leaves taken 60 days after full bloom.

$\mathrm{Fe}(120 \mathrm{~d})=\mathrm{Fe}$ content of leaves taken 120 days after full bloom.

$\mathrm{Fe}(\mathrm{fl})=\mathrm{Fe}$ content of flowers.

$\mathrm{Mn}(60 \mathrm{~d})=\mathrm{Mn}$ content of leaves taken 60 days after full bloom.

$\mathrm{Mn}(120 \mathrm{~d})=\mathrm{Mn}$ content of leaves taken 120 days after full bloom.

$\mathrm{Mn}(\mathrm{fl})=\mathrm{Mn}$ content of flowers. 